\title{
Analisis Kebutuhan Alat dan Mesin Pertanian Untuk Mendukung Pengembangan Usaha Tani Padi Di Kawasan Kota Terpadu Mandiri (KTM) Mesuji, Provinsi Lampung
}

\author{
Mohamad Haifan ${ }^{1, \text { a) }}$ \\ ${ }^{1}$ Dosen Tetap Prodi Teknik Mesin Otomotif, Institut Teknologi Indonesia \\ J1. Raya Pupsiptek, Serpong, Kota Tangerang Selatan, Banten, Indonesia 15320 \\ a) $\underline{\text { haifanmohamad1963@gmail.com }}$
}

\begin{abstract}
Abstrak
Guna mewujudkan ketersediaan pangan (beras) dalam rangka menciptakan ketahanan pangan, pemerintah mengembangkan kawasan Kota Terpadu Mandiri (KTM) Mesuji. Alokasi pengembangan tanaman pangan padi di KTM Mesuji seluas $9.900 \mathrm{Ha}$ atau 21 persen dari total luas kawasan KTM. Untuk mendukung hal tersebut, penggunaan alat dan mesin pertanian (alsintan) diharapkan mampu mengatasi permasalahan ketersediaan tenaga kerja, sehingga diharapkan dapat meningkatkan produktivitas kerja dan produksi usaha tani. Penelitian ini bertujuan menganalisis kebutuhan alsintan untuk mendukung program pengembangan usaha tani padi di KTM Mesuji. Metode penelitian yang digunakan adalah metode diskriptif kuantitatif dengan pengambilan sampel secara purposive. Pengambilan sampel wilayah dipilih 10 desa yang masuk dalam kawasan KTM sebagai sampel obyek yang diteliti. Hasil penelitian menunjukkan bahwa pemerintah telah memberikan bantuan beberapa jenis alsintan untuk mendukung program pengembangan dan peningkatan produksi padi di KTM Mesuji. Jenis alsintan yang telah memenuhi jumlahnya sesuai kebutuhan, yaitu Handtractor dan Rice Milling Unit (RMU), sedangkan jenis alsintan yang masih belum memenuhi jumlah sesuai kebutuhan adalah Pompa Air, Rice Transplanter, Power Thresher dan Mini Combine Harvester. Rekomendasi hasil penelitian ini diharapkan pemerintah dapat mengalokasikan bantuan alsintan yang dibutuhkan secara bertahap, sehingga kinerja usaha tani dapat optimal.
\end{abstract}

Kata Kunci : Kebutuhan Alsintan, KTM Mesuji, Produksi Beras

\begin{abstract}
To realize the availability of food (rice) in order to create food security, the government developed "Kota Terpadu Mandiri (KTM)" Mesuji. The allocation of the development of food crops of rice in KTM Mesuji area of 9,900 hectares or 21 percent of the total area of KTM. To support this, the use of agricultural farm machineries is expected to overcome problems of availability of labor, which is expected to increase labor productivity and production farm. This study aimed to analyze the needs alsintan to support the development of rice farming in the KTM Mesuji. The method used is quantitative descriptive method with purposive sampling. The sampling area selected 10 villages were included in the sample area of KTM as the object studied. The results showed that the government had provided some kind Farm Machineries to support the development and enhancement of rice production in KTM Mesuji. Farm Machineries types that have met in number according to needs, namely Handtractor and Rice Milling Unit (RMU), while the type of alsintan who still do not meet the number as needed is Water Pump, Rice Transplanter, Power Thresher and Mini Combine Harvester. Recommendations on these results the government is expected to meet the amount and type of the required Farm machineries gradually, so that performance can be optimized farming.
\end{abstract}

Keyword : KTM Mesuji, Need of Farm Machineries, Rice Production

\section{PENDAHULUAN}

Upaya strategis yang dilakukan oleh pemerintah untuk mewujudkan pembangunan pertanian guna mendukung ketahanan pangan diarahkan pada lahan-lahan yang terdapat di luar pulau Jawa, karena luas lahan masih sangat memungkinkan untuk dikembangkan sebagai lahan pertanian. Salah satu program pemerintah untuk merealisasikan maksud tersebut adalah program transmigrasi yang dikelola oleh Kementerian Desa, Pembangunan Daerah Tertinggal dan Transmigrasi.

Saat ini terjadi perubahan paradigma penyelenggaraan transmigrasi, tidak hanya 
bertujuan untuk pemerataan persebaran penduduk, namun juga strategi pengembangan wilayah. Dalam hal ini, pengembangan wilayah dan pembangunan di wilayah tujuan menjadi hal yang penting dari pada sekedar pemindahan dan pemerataan penduduk [1]. Perwujudan dari paradigma tersebut adalah pembangunan Kota Terpadu Mandiri (KTM). Secara definisi, KTM adalah kawasan transmigrasi yang pembangunan dan pengembangannya dirancang menjadi pusat pertumbuhan yang mempunyai fungsi perkotaan melalui pengelolaan sumberdaya alam yang berkelanjutan [2].

Lokasi-lokasi transmigrasi berupa Satuan Permukiman (SP) di Kabupaten Mesuji, Provinsi Lampung telah dibuka sejak tahun 1990 [3]. UPT-UPT tersebut disatukan membentuk kawasan KTM Mesuji. KTM Mesuji sebagai salah satu KTM yang oleh pemerintah diarahkan untuk dikembangkan sebagai lahan produksi padi. Berdasarkan tataguna lahan kawasan KTM Mesuji, rencana alokasi untuk pengembangan tanaman pangan padi seluas $9.900 \mathrm{Ha}$ atau 21 persen dari total kawasan KTM [4]. Potensi ketersediaan lahan ini akan mendukung program pengembangan dan penyediaan pangan padi (beras), khususnya di kawasan KTM dan sekitarnya dan secara umum membantu menciptakan ketahanan pangan nasional.

Rangkaian kegiatan usaha tani tanaman padi dimulai dari kegiatan pengolahan tanah, penanaman, pemeliharaan tanaman, panen dan pascapanen memerlukan tenaga kerja yang cukup banyak, terutama kegiatan pengolahan tanah, penanaman, panen dan pascapanen. Kegiatan tersebut harus dilakukan secara serempak dan tepat waktu, hal ini untuk menyesuaikan kondisi iklim dan pola usaha tani. Salah satu contoh, keterlambatan pada saat pengolahan tanah akan berakibat mundurnya penanaman, sehingga berpengaruh pada pola tanam dan pada akhirnya akan mengakibatkan tingkat produksi yang dihasilkan.

Di sisi lain, ketersediaan tenaga kerja manusia di kawasan KTM Mesuji masih sedikit, sehingga tidak mampu mendukung kegiatan usaha tani padi dengan baik yang mengakibatkan keterlambatan dalam setiap rangkaian kegiatan usaha tani. Dengan demikian, hal ini menjadi permasalahan kegiatan usaha tani padi di kawasan KTM Mesuji.

Penerapan Mekanisasi Pertanian, dalam hal ini penggunaan alsintan untuk mendukung kegiatan usaha tani padi diharapkan mampu mengatasi permasalahan ketersediaan tenaga kerja. Kekurangan tenaga kerja yang disertai dengan naiknya upah tenaga kerja mendorong petani untuk menggunakan alsintan, seperti traktor tangan (hand tractor), mesin pemanen, mesin perontok dan penggilingan padi. Dukungan alsintan, selain untuk meningkatkan luas garapan dan intensitas tanam, juga untuk meningkatkan produktivitas dan efisiensi usahatani, menekan kehilangan hasil serta meningkatkan mutu dan nilai tambah hasil pertanian [5].

Pemerintah melalui Kementerian Desa, Pembangunan Daerah Tertinggal dan Transmigrasi telah memberikan bantuan alsintan kepada pengelola KTM yang dimanfaatkan dan dikelola oleh kelompok tani di masing-masing desa. Namun, jumlah beberapa jenis alsintan tersebut masih belum memenuhi sesuai dengan kebutuhan di lapangan. Untuk itu, perlu dilakukan kajian terkait dengan ketersediaan jumlah dan jenis alsintan terhadap kebutuhan sesuai dengan kapasitas kerja untuk masingmasing alsintan. Penelitian ini bertujuan untuk mengetahui kesenjangan antara ketersediaan dan kebutuhan, baik jumlah maupun jenis alsintan untuk mendukung kegiatan usaha tani secara optimal di KTM Mesuji. Hasil penelitian ini diharapkan menjadi bahan rekomendasi kepada pemerintah untuk memenuhi kekurangan, baik jumlah maupun jenis alsintan yang dibutuhkan di lapangan. Selain itu, hal ini juga dapat menjadi peluang usaha jasa penyewaan alsintan oleh masyarakat atau kelompok tani yang diharapkan dapat menumbuhkan kewirausahaan di kawasan KTM.

\section{LANDASAN TEORI}

\section{Kota Terpadu Mandiri (KTM) Mesuji}

Pembangunan Transmigrasi merupakan bagian integral dari pembangunan nasional dan daerah, sebagai upaya untuk mempercepat pembangunan di kawasan yang terisolir/ tertinggal. Beberapa tahun terakhir, terjadi perubahan orentasi pada penyelenggaraan transmigrasi. Pada awalnya, tujuan utama transmigrasi adalah untuk pemerataan dan persebaran penduduk, selanjutnya orentasi bergeser ke paradigma pembangunan wilayah. Pengembangan wilayah dan pembangunan di wilayah tujuan menjadi hal yang penting dibandingkan sekedar pemindahan dan pemerataan persebaran penduduk [1]. Pembangunan Kota Terpadu Mandiri (KTM) di kawasan transmigrasi merupakan bagian dari realisasi paradigma baru tersebut.

Pembangunan dan pengembangan KTM di Kawasan Transmigrasi bertujuan menciptakan sentra-sentra agribisnis dan agroindustri yang mampu menarik investasi swasta, sebagai penggerak perekonomian transmigran dan penduduk sekitar, menjadi pusat-pusat pertumbuhan baru, sekaligus membuka kesempatan kerja dan peluang berusaha [6]. 
Pusat kegiatan agribisnis yang dikembangkan dalam sebuah KTM mencakup antara lain : pengembangan wilayah pengolahan hasil pertanian menjadi barang produksi dan/ atau barang konsumsi, pengembangan pusat pelayanan agroindustri khusus (special agroindustry services) dan pemuliaan tanaman unggul, serta pengembangan pusat pendidikan dan pelatihan di sektor pertanian, industri dan jasa. KTM diharapkan menjadi pusat perdagangan wilayah, sehingga dilengkapi dengan adanya lembaga keuangan, pasar grosir dan perdagangan [7].

Luas lahan yang dialokasikan di wilayah KTM Mesuji seluas $46.560 \mathrm{Ha}$ yang meliputi Kawasan Lindung seluas $890 \mathrm{Ha}(1,91 \%)$, Pemukiman seluas 7.070 Ha $(15,2 \%)$, Pengembangan Perkebunan Besar Kelapa Sawit seluas 8.900 Ha $(19,1 \%)$, Pengembangan Tanaman Pangan Jagung seluas $8.100 \mathrm{Ha}$ $(17,4 \%)$, Pengembangan Tanaman Padi seluas 9.900 Ha $(21,2 \%)$ dan Pengembangan Tanaman Perkebunan Rakyat (Kelapa Sawit atau Karet) seluas $11.700 \mathrm{Ha}(25,1 \%)$ [4].

Kawasan KTM Mesuji meliputi empat kecamatan, yaitu kecamatan Mesuji, Kecamatan Mesuji Timur, Kecamatan Tanjung Raya dan Kecamatan Simpang Pematang. Posisi geografis terdapat pada $03^{\circ} 45^{\prime}-04^{\circ} 5^{\prime}$ Lintang Selatan dan $105^{\circ} 07^{\prime}-105^{\circ} 38^{\prime}$ Bujur Timur. Lokasi transmigrasi yang masuk dalam kawasan KTM adalah Kawasan Transmigrasi Mesuji Atas yang terdiri atas Satuan Permukiman (SP) 1 sampai dengan 13 dan Kawasan Mesuji $F$ terdiri atas Satuan Permukiman (SP) 1 sampai dengan 3, serta Kawasan Mesuji A, B, C, D dan F. Total penduduk di kawasan ini sebanyak 111.203 jiwa atau $29.552 \mathrm{KK}$.

\section{Alsintan Dalam Pengelolaan Usahatani}

Masalah utama dalam pengembangan pertanian di lahan pasang surut adalah terbatasnya modal dan tenaga kerja yang bekerja pada rangkaian kegiatan usaha tani. Sebagai alternatif pemecahan masalah tersebut adalah memanfaatkan alat dan mesin pertanian (alsintan) produksi dan pascapanen tepat guna [5]. Penggunaan alsintan pada usaha tani padi, selain dapat meningkatkan luas garapan, juga untuk mengatasi kelangkaan/ keterbatasan tenaga kerja. Di kawasan lahan pasang surut, rasio luas lahan dengan jumlah petani di permukiman kurang berimbang karena luas rata-rata yang dimiliki 2,08 - 2,20 Ha, sedangkan kemampuan garap lahan per keluarga tani sekitar $1 \mathrm{Ha}$ [8]. Dengan penggunaan alsintan dapat meningkatkan pemanfaatan lahan untuk usaha tani, intensitas tanam dan keserempakan pengelolaan usaha tani, sehingga dapat mengurangi terjadinya serangan hama dan penyakit tanaman.

Peggunaan alat pengolah tanah dengan sumber penggerak traktor (hand tractor atau mini tractor) dapat merubah sistem dan pola tanam, memperpendek waktu kerja (peningkatan efisiensi), menyeragamkan waktu tanam dan membuka lahan garapan yang lebih luas. Peningkatan efisiensi pada penggunaan hand tractor di lahan pasang surut cukup tinggi sekitar 76 - 80 persen dibandingkan secara manual [9].

Selain kegiatan pengolahan tanah, kegiatan penanaman juga memerlukan tenaga kerja yang banyak dan dalam waktu yang bersamaan untuk mendapatkan penanaman yang serempak. Cara tanam pindah di lahan sawah membutuhkan tenaga kerja sekitar 26 persen dari total tenaga kerja usaha tani seluruhnya sebesar $173 \mathrm{HOK}$ [10]. Untuk mengatasi hal tersebut, telah dikembangkan alat tanam benih langsung (atabela 6 alur) untuk lahan pasang surut dengan kapasitas kerja $0,083 \mathrm{Ha} /$ jam dengan dua orang operator [11].

Kegiatan panen adalah tahapan akhir rangkaian produksi padi yang dianggap sangat kritis, karena kelangkaan tenaga kerja yang sering muncul pada saat akan dilaksanakan panen. Akibatnya waktu panen tertunda atau mundur yang menyebabkan terjadinya susut panen yang besar sekitar $6-9$ persen. Kegiatan panen harus dilakukan pada saat yang tepat untuk menghindari terjadi susut selama panen, terutama untuk varitas padi yang mudah rontok. Kebutuhan tenaga kerja untuk panen hampir 25 pesen dari total tenaga kerja usaha tani. Mesin pemanen (reaper, mini combine harester) telah digunakan pada lahan pasang surut yang dapat menurunkan susut panen sekitar 0,1 persen sampai maksimum 2 persen dengan waktu yang dibutuhkan semakin pendek [12]. Kapasitas kerja mesin panen reaper untuk pemotongan atas sebesar 0,187 Ha/ jam, sedangkan untuk pemotongan bawah sebesar 0,167 Ha/jam. Kesetaraan waktu kerja panen dengan mesin reaper dibanding tenaga manusia sebesar 23,40 Ha dan dengan sabit sebesar 14,70 Ha [10].

Upaya menghindari terjadinya susut pascapanen padi yang lebih tinggi, perlu segera dilakukan perontokan. Akibat penumpukan padi setelah panen yang tidak segera dilakukan perontokan akan mengakibatkan kerusakan pada gabah. Beras yang dihasilkan dari padi yang lama ditumpuk lama, diantaranya beras berbintik dan persentase beras pecah yang tinggi saat penggilingan. Hasil pengujian mesin perontok di lahan pasang surut Sumatera Selatan dapat memperpendek waktu perontokan dari 18 jam/ Ha menjadi $12 \mathrm{jm} / \mathrm{Ha}$. Kehilangan (susut) selama perontokan dengan cara digebot (manual) 
sebesar 16,20 persen, sedangkan dengan Power Thresher sebesar 3,30 persen [5].

Tahapan penanganan pascapenen padi berikutnya yang sangat penting adalah pengeringan gabah, hal ini berkaitan dengan kualitas beras yang dihasilkan pada proses penggilingan. Di lahan pasang surut, panen padi varitas unggul dilaksanakan pada periode bulan Januari sampai akhir Pebruari. Pada saat itu, curah hujan masih cukup tinggi, sehingga tidak memungkinkan dilakukan penjemuran. Untuk itu, perlu mesin pengering agar gabah dapat segera dikeringkan untuk menghindari kerusakan (susut) pada saat penggilingan. Di lokasi pasang surut di KTM Mesuji, mesin pengering (bed dryer) biasanya ditempatkan menyatu di lokasi Rice Milling Unit (RMU) atau Rice Milling Plant (RMP) skala besar, sehingga lebih praktis dan efektif karena pengangkutan gabah untuk dilakukan pengeringan dan langsung penggilingan.

Penggilingan gabah menjadi beras merupakan tahapan akhir proses pascapanen padi sebelum disimpan atau dipasarkan. Di wilayah KTM Mesuji mesin giling berupa RMU dan RMP berada di sekitar sentra produksi. RMU adalah mesin penggilingan gabah dengan kapasitas kecil sekitar 150 - $200 \mathrm{~kg}$ / jam, sedangkan kapasitas RMP mencapai 3 ton/ jam. Di lokasi KTM Mesuji hanya terdapat satu unit RMP berlokasi di Desa Wonosari yang diharapkan dapat memberikan layanan seluruh areal produksi padi, sedangkan jumlah RMU cukup banyak yang biasanya dikelola oleh pribadi/ swasta.

\section{METODE PENELITIAN}

Kegiatan penelitian dilaksanakan di kawasan KTM Mesuji, Provinsi Lampung. Waktu pelaksanaan kegiatan antara bulan Agustus sampai Desember 2015.

Metode penelitian menggunakan pendekaatan metode diskriptif-kuantitatif dengan pengambilan sampel secara purposive. Pengambilan sampel wilayah dipilih 10 desa yang masuk dalam kawasan KTM sebagai sampel obyek yang diteliti meliputi : Desa Tanjung Mas Makmur, Desa Pangkal Mas, Desa Tanjung Mas Mulya, Desa Pangkal Mas Jaya, Desa Wonosari, Desa Tanjung Mas Jaya, Desa Tanjung Mas Rejo, Desa Eka Mulya dan Desa Dwi Karya Mustika.

Pengumpulan data dilakukan dengan survei dan wawancara semi terstruktur dengan informan kunci, yaitu pengelola KTM, ketua kelompok tani dan pengelola alsintan di lapangan. Selanjutnya data diolah secara diskriptif dan dianalisis dengan membandingkan jenis dan jumlah alsintan yang tersedia di lapangan dengan yang seharusnya berdasarkan kapasitas layanan untuk masing-masing jenis alsintan.

\section{HASIL DAN PEMBAHASAN}

\section{Identifikasi Ketersediaan Alsintan Di 10 Desa Sampel Di KTM Mesuji}

Identifikasi ketersedian alsintan di 10 desa sampel di KTM Mesuji seperti disajikan pada Tabel 1. Ketersediaan alsintan di 10 desa sampel, tidak hanya bantuan dari pemerintah pusat melalui APBN, tetapi juga bantuan pemerintah daerah melalui APBD dan kepemilikan pribadi petani di kawasan KTM Mesuji.

Tabel 1. Ketersediaan alsintan di 10 desa sampel di KTM Mesuji

\begin{tabular}{|c|c|c|c|c|c|c|c|c|c|c|c|}
\hline \multirow[b]{2}{*}{ Jenis Alsintan } & \multicolumn{10}{|c|}{ 10 Desa Sampel di Wilayah KTM Mesuji } & \multirow[b]{2}{*}{ Jumlah } \\
\hline & $\begin{array}{l}\text { Tanjung } \\
\text { Mas } \\
\text { Makmur }\end{array}$ & $\begin{array}{c}\text { Pangkal } \\
\text { Mas }\end{array}$ & $\begin{array}{c}\text { Tanjung } \\
\text { Mas } \\
\text { Mulya }\end{array}$ & $\begin{array}{c}\text { Pangkal } \\
\text { Mas } \\
\text { Mulya }\end{array}$ & $\begin{array}{c}\text { Pangkal } \\
\text { Mas } \\
\text { Jaya }\end{array}$ & Wonosari & $\begin{array}{c}\text { Tanjung } \\
\text { Mas } \\
\text { Jaya }\end{array}$ & $\begin{array}{c}\text { Tanjung } \\
\text { Mas } \\
\text { Rejo }\end{array}$ & $\begin{array}{c}\text { Eka } \\
\text { Mulya }\end{array}$ & $\begin{array}{c}\text { Dwi } \\
\text { Karya } \\
\text { Mustik } \\
\text { a } \\
\end{array}$ & \\
\hline Luas Lahan (Ha) & 112 & 569 & 400 & 546 & 230 & 691 & 319 & 133 & 50 & 539 & 3.589 \\
\hline Hand Tractor & 27 & 35 & 24 & 47 & 22 & 25 & 10 & 8 & 0 & 15 & 213 \\
\hline Pompa Air & 7 & 5 & 10 & 10 & 3 & 2 & 4 & 20 & 2 & 6 & 69 \\
\hline Rice & 0 & - & 1 & & 1 & 1 & 1 & - & - & - & 4 \\
\hline \multicolumn{12}{|l|}{ Transplanter } \\
\hline Power Thresher & 8 & 20 & 12 & 9 & 77 & 9 & 8 & 6 & 0 & 2 & 151 \\
\hline Mini Combine & 1 & 1 & 1 & & 1 & & 1 & 1 & & & 6 \\
\hline RMU & 6 & 6 & 5 & 6 & 4 & 6 & 7 & 6 & 0 & 5 & 51 \\
\hline RMP & 0 & 0 & 0 & 0 & 0 & 1 & 0 & 0 & 0 & 0 & 1 \\
\hline
\end{tabular}

Analisis Ketersediaan dan Kebutuhan Alsintan di KTM Mesuji

Kapasitas kerja lapang alsintan dipengaruhi oleh beberapa faktor, diantaranya (1) Situasi dan kondisi lahan, (2) Ketrampilan operator, (3) Persiapan dan mobilitas alsintan. Ketiga faktor tersebut menjadi hal penting, sehingga pemanfaatan alsintan untuk membantu kegiatan usaha tani menjadi lebih efisien dan efektif. 
Analisis ketersediaan atau kecukupan jumlah alsintan untuk mendukung kegiatan usaha tani sangat ditentukan oleh kapasitas kerja alsintan, hari kerja dan luas layanan untuk masing-masing jenis alsintan. Dari hasil beberapa penelitian didapatkan kapasitas alsintan, hari kerja dan luas layanan untuk masing-masing jenis alsintan seperti terlihat pada Tabel 2.

Tabel 2. Jenis alsintan, kapasitas kerja, hari kerja dan luas layanan untuk masing-masing alsintan

\begin{tabular}{llccc}
\hline No & Nama Alsintan & Kapasitas Alat & Hari Kerja/Musim & $\begin{array}{c}\text { Luas Layanan } \\
\text { (Ha/Unit) }\end{array}$ \\
\hline 1 & Hand Tractor & 0.4 Ha/Hari & 30 & 20 \\
2 & Mesin Pompa Air & 7 & 15 & 15 \\
3 & Hand Spayer & 0 & 12 & 12 \\
4 & Rice Transplanter & $1,5 \mathrm{Ha} /$ hari & 15 & 22,5 \\
6 & Power Threasher & 8 & 34 & 34 \\
7 & Mini Reaper & 1 & 35 & 35 \\
8 & RMU & 65 & 60 & 60 \\
9 & RMP & 0 & 3000 & 3000 \\
\hline
\end{tabular}

Sumber : Kementerian Pertanian, 2005

Guna mengetahui apakah ketersediaan masing-masing jenis alsintan yang ada saat ini di 10 desa sampel di KTM telah mencukupi, maka dilakukan perhitungan yang didasarkan pada identifikasi alsintan di masing-masing 10 desa sampel. Hasil perhitungan ketersediaan atau kecukupan untuk masing-masing jenis alsintan kegiatan produksi disajikan pada Tabel 3 .

Tabel 3. Analisis ketersediaan dan kebutuhan alsintan produksi

\begin{tabular}{|c|c|c|c|c|c|c|c|c|c|c|c|}
\hline \multirow{2}{*}{ Jenis Alsintan } & \multicolumn{10}{|c|}{ 10 Desa Sampel di Wilayah KTM Mesuji } & \multirow[t]{2}{*}{ Jumlah } \\
\hline & $\begin{array}{l}\text { Tanjung } \\
\text { Mas } \\
\text { Makmur }\end{array}$ & $\begin{array}{c}\text { Pangkal } \\
\text { Mas }\end{array}$ & $\begin{array}{l}\text { Tanjung } \\
\text { Mas } \\
\text { Mulya }\end{array}$ & $\begin{array}{c}\text { Pangkal } \\
\text { Mas } \\
\text { Mulya }\end{array}$ & $\begin{array}{c}\text { Pangkal } \\
\text { Mas } \\
\text { Jaya }\end{array}$ & Wonosari & $\begin{array}{c}\text { Tanjung } \\
\text { Mas } \\
\text { Jaya }\end{array}$ & $\begin{array}{c}\text { Tanjung } \\
\text { Mas } \\
\text { Rejo }\end{array}$ & $\begin{array}{c}\text { Eka } \\
\text { Mulya }\end{array}$ & $\begin{array}{c}\text { Dwi } \\
\text { Karya } \\
\text { Mustik } \\
\text { a }\end{array}$ & \\
\hline $\begin{array}{l}\text { Luas Lahan (Ha) } \\
\text { Hand Tractor }\end{array}$ & 112 & 569 & 400 & 546 & 230 & 691 & 319 & 133 & 50 & 539 & 3.589 \\
\hline Ketersediaan (unit) & 27 & 35 & 24 & 47 & 22 & 25 & 10 & 8 & 0 & 15 & 213 \\
\hline $\begin{array}{l}\text { Kebutuhan ( } 20 \\
\text { ha/unit) }\end{array}$ & 6 & 29 & 20 & 28 & 12 & 35 & 16 & 7 & 3 & 27 & 183 \\
\hline $\begin{array}{l}\text { Kelebihan (+)/ } \\
\text { Kekurangan (-) } \\
\text { Pompa Air }\end{array}$ & 21 & 6 & 4 & 19 & 10 & -10 & -6 & 1 & -3 & -12 & 30 \\
\hline Ketersediaan (unit) & 7 & 5 & 10 & 10 & 3 & 2 & 4 & 20 & 2 & 6 & 69 \\
\hline $\begin{array}{l}\text { Kebutuhan (15 } \\
\text { ha/unit) }\end{array}$ & 8 & 38 & 27 & 37 & 16 & 47 & 22 & 9 & 4 & 36 & 244 \\
\hline $\begin{array}{l}\text { Kelebihan (+)/ } \\
\text { Kekurangan (-) }\end{array}$ & -1 & -33 & -17 & -27 & -13 & -45 & -18 & 11 & -2 & -30 & -175 \\
\hline Rice Transplanter & & & & & & & & & & & \\
\hline $\begin{array}{l}\text { Ketersediaan (unit) } \\
\text { Kebutuhan (18 } \\
\text { ha/unit) }\end{array}$ & $\begin{array}{l}0 \\
7\end{array}$ & 32 & $\begin{array}{c}1 \\
23\end{array}$ & $\begin{array}{c}- \\
31\end{array}$ & $\begin{array}{c}1 \\
13\end{array}$ & $\begin{array}{c}1 \\
39\end{array}$ & $\begin{array}{c}1 \\
18\end{array}$ & $\overline{8}$ & - & $\begin{array}{c}- \\
30\end{array}$ & $\begin{array}{c}4 \\
204\end{array}$ \\
\hline $\begin{array}{l}\text { Kelebihan (+)/ } \\
\text { Kekurangan (-) }\end{array}$ & -7 & -32 & -22 & -31 & -12 & -38 & -17 & -8 & -3 & -30 & -200 \\
\hline
\end{tabular}


Pada Tabel 3 menunjukkan bahwa, total ketersediaan Hand Tractor di KTM Mesuji sebanyak 213 unit, sedangkan kebutuhannya sebanyak 180 unit, sehingga terdapat selisih sebanyak 33 unit. Dengan demikian, ketersediaan Hand Tractor di KTM Mesuji sudah memadai, dimana secara keseluruhan terdapat kelebihan sebanyak 33 unit. Namun, jika dilihat ketersediaan Hand Tractor di 10 desa sampel terdapat kekurangan, yaitu Desa Wonosari sebanyak 10 unit, Desa Tanjung Mas Jaya sebanyak 6 unit, Desa Eka Mulya sebanyak 3 unit dan Desa Dwi Karya Mulia sebanyak 12 unit. Upaya untuk mengatasi hal tersebut, perlu dilakukan alokasi dan distribusi Hand Tractor (terutama bantuan pemerintah) secara merata susuai dengan luas layanan di seluruh desa dan kawasan KTM Mesuji. Hal ini juga dapat dilakukan untuk jenis alsintan yang lain.

Ketersediaan Mesin Pompa Air di KTM Mesuji sebanyak 69 unit, sedangkan jumlah yang dibutuhkan sebanyak 239 unit, sehingga terdapat kekurangan sebanyak 171 unit. Sementara itu, jika dilihat di 10 desa sampel, hanya 1 (satu) desa yaitu Desa Tanjung Mas Rejo yang memiliki kelebihan pompa air sebanyak 11 unit, sedangkan di 9 (Sembilan) desa dampingan lainnya dalam kondisi kekurangan pompa air yang jumlahnya bervariasi.

Untuk dapat melakukan kegiatan penanaman yang serentak diperlukan tenaga kerja manusia yang cukup banyak, sedangkan kondisi tenaga kerja di lokasi KTM Mesuji sangat terbatas, sehingga untuk mewujudkan tujuan tersebut diperlukan bantuan Rice Transplanter yang memadai. Jika dilihat total ketersediaan Rice Transplanter di KTM Mesuji sebanyak 4 unit, sementara itu kebutuhannya sebanyak 199 unit, sehingga terjadi kekurangan sebanyak 196 unit. Kekurangan Rice Transplanter tercatat di 10 desa dampingan di KTM Mesuji.

Sementara itu, analisis ketersediaan dan kebutuhan alsintan panen dan pasca panen di 10 desa dampingan dan di KTM Mesuji disajikan pada Tabel 4. 
Tabel 4. Analisis ketersediaan dan kebutuhan alsintan pascapanen

\begin{tabular}{|c|c|c|c|c|c|c|c|c|c|c|c|}
\hline \multirow[t]{2}{*}{ Jenis Alsintan } & \multicolumn{10}{|c|}{ 10 Desa Sampel di Wilayah KTM Mesuji } & \multirow{2}{*}{ Jumlah } \\
\hline & $\begin{array}{c}\text { Tanjung } \\
\text { Mas } \\
\text { Makmur }\end{array}$ & $\begin{array}{c}\text { Pangkal } \\
\text { Mas }\end{array}$ & $\begin{array}{c}\text { Tanjung } \\
\text { Mas } \\
\text { Mulya }\end{array}$ & $\begin{array}{c}\text { Pangkal } \\
\text { Mas } \\
\text { Mulya }\end{array}$ & $\begin{array}{c}\text { Pangkal } \\
\text { Mas } \\
\text { Jaya }\end{array}$ & Wonosari & $\begin{array}{c}\text { Tanjung } \\
\text { Mas } \\
\text { Jaya }\end{array}$ & $\begin{array}{c}\text { Tanjung } \\
\text { Mas } \\
\text { Rejo }\end{array}$ & $\begin{array}{c}\text { Eka } \\
\text { Mulya }\end{array}$ & $\begin{array}{c}\text { Dwi } \\
\text { Karya } \\
\text { Mustik } \\
\text { a } \\
\end{array}$ & \\
\hline Luas Lahan (Ha) & 112 & 569 & 400 & 546 & 230 & 691 & 319 & 133 & 50 & 539 & 3.589 \\
\hline Mini Combine & & & & & & & & & & & \\
\hline Ketersediaan (unit) & 1 & 1 & 1 & 0 & 1 & 0 & 1 & 1 & 0 & 0 & 6 \\
\hline $\begin{array}{l}\text { Kebutuhan (30 } \\
\text { ha/unit) }\end{array}$ & 4 & 19 & 14 & 19 & 8 & 23 & 11 & 5 & 2 & 18 & 123 \\
\hline $\begin{array}{l}\text { Kelebihan (+)/ } \\
\text { Kekurangan (-) } \\
\text { Power Thresher }\end{array}$ & -3 & -18 & -13 & -19 & -7 & -23 & -10 & -4 & -2 & -18 & -117 \\
\hline Ketersediaan (unit) & 8 & 20 & 12 & 9 & 77 & 9 & 8 & 6 & 0 & 2 & 151 \\
\hline $\begin{array}{l}\text { Kebutuhan (20 } \\
\text { ha/unit) }\end{array}$ & 6 & 29 & 20 & 28 & 12 & 35 & 16 & 7 & 3 & 27 & 183 \\
\hline $\begin{array}{l}\text { Kelebihan (+)/ } \\
\text { Kekurangan (-) } \\
\boldsymbol{R M U}\end{array}$ & 2 & -9 & -8 & -19 & 65 & -26 & -8 & -1 & -3 & -25 & -32 \\
\hline Ketersediaan (unit) & 6 & 6 & 5 & 6 & 4 & 6 & 7 & 6 & 0 & 5 & 51 \\
\hline $\begin{array}{l}\text { Kebutuhan (100 } \\
\text { ha/unit) }\end{array}$ & 2 & 6 & 4 & 6 & 3 & 7 & 4 & 2 & 1 & 6 & 41 \\
\hline $\begin{array}{l}\text { Kelebihan (+)/ } \\
\text { Kekurangan (-) }\end{array}$ & 4 & 0 & 1 & 0 & 1 & -1 & 3 & 4 & -1 & -1 & 10 \\
\hline
\end{tabular}

Pada Tabel 4 menunjukkan kegiatan panen menggunakan Mini Combine Harvester dengan kapasitas $0,2 \mathrm{Ha} / \mathrm{Jam}$ atau 1,4 $\mathrm{Ha} / \mathrm{Hari}$, maka kapasitas Mini Combine Harvester yang ada hanya bisa melayani sebesar $28-30 \mathrm{Ha} /$ Unit $(1,4$ Ha x 20-22 Hari/musim), maka dibutuhkan Mini Combine Harvester sebanyak 19 unit . Dengan demikian dibutuhkan sebanyak 7 unit Mini Combine Harvester, sementara jumlah Mini Combine Harvester yang tersedia berjumlah 3 unit, terdapat kekurangan Mini Combine Harvester sebanyak 4 unit

Sementara itu, ketersediaan Power Thresher di KTM Mesuji sebanyak 151 unit, sedangkan hasil perhitungan kebutuhannya sebanyak 179 unit, sehingga terjadi kekurangan sebanyak 29 unit. Jika dilihat di 10 desa sampel, terdapat kelebihan di beberapa desa, diantaranya Desa Tanjung Mas Makmur sebanyak 2 unit dan Desa Pangkal Mas Jaya sebanyak 65 unit. Untuk itu perlu pengaturan atau distribusi Power Thresher secara merata sesuai luas layanan di seluruh desa dampingan lainnya agar alsintan tersebut dapat dimanfaatkan secara optimal.

Kegiatan pengolahan/ penggilingan padi menjadi beras di KTM Mesuji diperlukan RMU sebanyak 36 unit, sedangkan ketersediaan RMU saat ini sebanyak 51 unit, sehingga terjadi kelebihan sebanyak 15 unit. Jika dilihat ketersediaan RMU di 10 desa dampingan, masih terdapat beberapa desa yang kekurangan RMU, yaitu Desa Wonosari sebanyak 1 unit, Desa Eka Mulya sebanyak 1 unit dan Desa Dwi Karya Mustika sebanyak 1 unit. Sebenarnya keberadaan RMP di Desa Wonosari dapat memberikan untuk luas layanan KTM Mesuji, namun saat ini terdapat beberapa kendala teknis dan social, sehingga RMP belum dapat dioperasikan secara optimal.

\section{KESIMPULAN}

Dari hasil analisis ketersediaan dan kebutuhan alsintan di KTM Mesuji didapatkan jenis alsintan yang telah memenuhi jumlahnya sesuai kebutuhan di lapangan, yaitu Hand Tractor dan Rice Milling Unit (RMU), sedangkan jenis alsintan yang masih belum memenuhi jumlah sesuai kebutuhan adalah Pompa Air, Rice Transplanter, Power Thresher dan Mini Combine Harvester. Kekurangan alsintan menjadi pertimbangan pemerintah dalam mengalokasikan bantuan alasintan ke kawasan KTM Mesuji. Selain itu, kondisi tersebut dapat menjadi peluang usaha masyarakat setempat untuk mengadakan usaha pelayanan jasa alsintan (UPJA).

\section{UCAPAN TERIMA KASIH}

Ucapan terima kasih ditujukan kepada PT. Shiddiq Sarana Mulya, Jakarta yang telah memfasilitasi pelaksanaan penelitian ini.

\section{REFERENSI}

[1] Sekretariat Negara RI. Undang-undang Republik Indonesia Nomor 29 Tahun 2009 Tentang Perubahan UU. No. 15 Tahun 1997 Tentang Ketransmigrasian. Lembaran Negara Republik Indonesia.

[2] Widiatmaka, B.D, Ginting-Soeka, M.A Nurdin. Pedoman Pembangunan Kota Terpadu Mandiri. Direktorat Jenderal Perencanaan Permukiman Transmigrasi. Kementerian Tenaga Kerja dan Transmigrasi, Jakarta, 2009.

[3] Tim Survei Tanah. Survei Tanah Semi-detail Daerah Pasang Surut Daerah Mesuji Atas, 
Proyek Pengembangan Persawahan Pasang Surut. Fakultas Pertanian, Institut Pertanian Bogor. 1990.

[4] Widiatmoko, Wiwin Ambarwulan, Budi Sutomo, Umar Hamzah, dan Prasetyoad Warsono. 2014. Perancangan Tataguna Lahan Dan Tata Ruang Kawasan Perkotaan Berbasis Pertanian: Studi Kasus KTM Transmigrasi Mesuji, Provinsi Lampung. Prosiding Seminar nasional Multidisplin Ilmu, Univesitas Budi Luhur. Jakarta. 10 Mei 2014. hal. 98-105

[5] Ananto, EE, 2001. Pengembangan Alat dan Mesin Pertanian Tanaman Pangan di daerah Pasang Surut, Sumatera Selatan. Prosiding Seminar Nasional Inovasi Alat dan Mesin Pertanian Untuk Agribisnis. Badan Litbang Pertanian Deptan Bekerjasama dengan Perteta 10-11 Juli. hal 120-141.

[6] Danarti. 2011. Akselarasi Perekonomian Masyarakat Transmigrasi Di Hinterland KTM Telang. Jurnal Ketransmigrasian. vol 28. no. 1 , hal 13-24.

[7] Najiyati, S, Susilo, 2011. Sinergitas Instansi Pemerintah Dalam Pembangunan Kota Terpadu Mandiri. Jurnal Ketransmigrasian, vol. 28, no. 2. hal 113-124.

[8] Noorginayuwati, Noor M, Djamhuri M, 1996. Identifikasi Sebab dan Akibat Degradasi Sumber Daya Lahan Gambut Dalam Perspektif Kebakaran Lahan. Makalah Pada Konggres III dan Seminar Nasional Masyarakat Konservasi Tanah dan Air. Malang 4-6 Desember

[9] Umar, S, Noor HD, 2007. Dukungan Alsintan dan Teknologi Produksi Terhadap Hasil Padi Di Lahan Pasang Surut Sumatera Selatan. Prosiding Seminar Nasional Mekanisasi Pertanian. BBP Mektan, Badan Litbang Pertanian Deptan. Bogor. 29-30 Nov. hal. 393402

[10] Astanto, Annto EE, 1999. Optimalisasi Sistem Penanganan Panen Padi Di Lahan Pasang Surut Sumatera Selatan. Bulletin Enjiniring Pertanian. vol. 7, hal. 1-11

[11] Umar, S, Harjono, 2000. Pengujian Teknis Kinerja Alat Tanam Benih Langsung di Lahan Pasang Surut Sumatera Selatan. Prosiding Seminar Pengelolaan Tanaman Pangan Lahan Rawa. Puslitbangtan, Banjarbaru. 4-5 Juli. hal. 243-249.

[12] Balai Besar Alsintan, 1999. Rencana Induk Penelitian dan Perekayasaan Alat dan Mesin Pertanian. Balai Besar Alsintan. Serpong. 